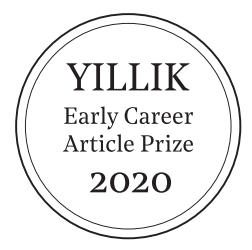

\title{
"May Those Who Understand What I Wrote Remember This Humble One": Paratextual Elements in Eighteenth-Century Ottoman Medical Manuscripts
}

\author{
Akif Ercihan Yerlioğlu*
}

\begin{abstract}
For students of early modern manuscript cultures, paratextual components are indispensable in inferring the ways in which people read, studied, and copied a codex. However, Ottoman manuscripts of medicine and healing have not been studied extensively by taking into account how their readers engaged with those texts. This article focuses on the entangled world of healing in eighteenthcentury Ottoman manuscript culture by using paratexts that connect widely circulated codices of the era to one another and demonstrates that boundaries between scholarly and popular medicine, or alchemy and medicine, were blurry for some readers. Moreover, examples of contributions and interventions from copyists and previous owners of manuscripts reveal the necessity to better understand these figures, other than medical professionals, who had an impact on the reception of medical texts.

Keywords: early modern reading culture, paratexts, Islamic manuscripts, alchemy, popular medicine

"Ne yazdığımı fehm idüp bu fakiri yâd eyleye": On Sekizinci Yüzyıl Osmanlı Tıp Yazmalarında Metin Dişı Unsurlar

Özet

Erken modern yazma kültürü araştırmacıları için ana metin dışı (paratextual) unsurlar, bir eserin nasıl okunmuş, çalışılmış ve istinsah edilmiş olduğu hakkında çıkarım yapmak için önemli ipuçları sunar. Bununla birlikte, Osmanlı tıp ve şifa yazmalarının nasıl okundukları konusunda kapsamlı çalışmalar yapılmamıştır. Bu makale, on sekizinci yüzyılın yaygın olarak okunan eserlerini birbiriyle bağlantılandıran metin dışı ögeleri mercek altına alarak dönemin şifa kültürünün karmaşıklığına odaklanmakta ve bu yolla, ilmi/popüler tıp ya da simya/tıp gibi alanlar arasındaki ayrımların bazı okurlar nezdinde daha bulanık olduğunu göstermektedir. Ayrıca, müstensihlerin ve kitapların önceki sahiplerinin metinlere yaptıkları yorum, katkı ve müdahalelere dair örnekler, tıbbi metinlerin nasıl algılandığı üzerinde etkisi olan ve tıp mesleğinin dışında kalan bu aktörleri daha iyi anlamamız gerektiğini ortaya koymaktadır.
\end{abstract}

Anahtar kelimeler: erken modern okuma kültürü, derkenar notları, İslam el yazmaları, simya, popüler tıp

Paratexts are "settings" for the textualization both of historical events and, at times, of the intimate impulses and emotions of individual people. In certain manuscripts, paratexts depict a more vivid picture of the historical role of manuscripts as real objects in the hands of real people; it is there that opinions, feelings, inclinations, etc. of the individuals involved in the production and transmission of manuscripts can find their textual transposition. ${ }^{1}$

Coined by the French literary theorist Gérard Genette, paratext is defined as any element that surrounds the main text (e.g., preface, title, illustrations) and has an effect "to make it present,

\footnotetext{
"University of Oslo, aeyerlioglu@gmail.com

I wish to thank Deniz Türker Cerda, Aslıhan Gürbüzel, Oscar Aguirre-Mandujano, K. Mehmet Kentel, Selim S. Kuru, and the anonymous reviewers for their insightful suggestions. I also gratefully acknowledge the support of Gerda Henkel Foundation.

1 Giovanni Ciotti and Hang Lin, eds., Tracing Manuscripts in Time and Space through Paratexts (Berlin: De Gruyter, 2016), VIIl.
} 
to assure its presence in the world, its 'reception' and consumption, in the form, nowadays at least, of a book." ${ }^{2}$ For students of Islamic manuscript cultures, paratextual components, not only those features shared by modern books such as the colophon and the title page but also manuscript notes (e.g., marginalia recorded by past owners) are indispensable in inferring the ways in which people read, studied, and copied a codex. A commentary on a particular section, a note identifying where the manuscript was read and whether other people accompanied the reading, an excerpt from another source on a related subject, an idiosyncratic complaint about the content of the text, or a mere scribble is not only an invaluable signpost for the afterlife of the manuscript but also one of the building blocks of a micro-history of a reading culture. ${ }^{3}$ Manuscripts that belong to the field of medicine and healing are no exception.

While we have begun to better understand the complex workings of early modern Ottoman medicine in terms of the theoretical discourses mobilized within it-thanks to recent works on medical texts of the period supported by rich archival materials-we still know very little about the production and consumption of medical manuscripts and the specific ways in which they were used. ${ }^{4}$ Here, notes taken by earlier readers of medical codices come to our rescue. This article cannot and does not aim to answer greater questions regarding medical manuscript culture; however, it aims to underscore the importance of readers' reception of these works and seeks to generate potential discursive trajectories towards making sense of how readers engaged with their texts by looking at manuscript notes and contextualizing these manuscripts and their owners. ${ }^{5}$ This article explores the entangled world of healing in eighteenth-century Ottoman manuscript culture by using specific manuscript notes that connect two widely-circulated codices: The Unique Gem on New Medicine (Cevherü'l-Ferid fitt-Tibbil'-Cedid) by Ömer Şifa'i (d. 1746) and What Medicine Entails (Ma Hazara fit-Tibb) by Nusret Efendi (d. 1793/1794). The former is a work produced by a distinguished physician, whereas the latter is a compilation of medical, spiritual, and talismanic remedies by a librarian interested in various genres. Focusing on the paratextual materials in a particular copy of The Unique Gem on New Me-

2 Gérard Genette and Marie Maclean, "Introduction to the Paratext," New Literary History 22, no. 2 (1991): 261-272. See also Genette, Paratexts: Thresholds of Interpretation (Cambridge: Cambridge University Press, 1997).

3 On the importance of manuscript notes in the larger world of Islamicate manuscripts, see Andreas Görke and Konrad Hirschler, eds., Manuscript Notes as Documentary Sources (Beirut: Ergon Verlag Würzburg in Kommission, 2011), especially Konrad Hirschler, "Reading Certificates (Samā‘āt) as a Prosopographical Source: Cultural and Social Practices of an Elite Family in Zangid and Ayyubid Damascus," in Hirschler, Manuscript Notes, 73-92; Boris Liebrenz, "An Archive in a Book: Documents and Letters from the Early-Mamluk Period," Der Islam 97, no. 1 (2020): 120-171; and the special issue of Journal of Islamic Manuscripts 9, no. 2/3, especially Elif Sezer Aydınlı, "Unusual Readers in Early Modern Istanbul," Journal of Islamic Manuscripts 9, no. 2/3 (2018): 109-131. See also Hellmut Ritter, "Autographs in Turkish Libraries," Oriens 6, no. 1 (1953): 63-90; Tülün Değirmenci, "Bir Kitabı Kaç Kişi Okur? Osmanlı'da Okurlar ve Okuma Biçimleri Üzerine Bazı Gözlemler," Tarih ve Toplum Yeni Yaklaşımlar, no. 13 (Güz 2011): 7-43; Meredith M. Quinn, "Making Sense of Miscellanies: Houghton Library MS Turk 11, an Ottoman Mecmua," Harvard Library Bulletin 24, no. 1 (2013): 27-44; and Berat Açıl, ed., Osmanlı Kitap Kültürü: Cârullah Efendi Kütüphanesi ve Derkenar Notları (Istanbul: Nobel-iLEM Kitaplığı, 2015). 4 For instance, Coşkun Y1lmaz and Necdet Yılmaz edited a volume consisting of articles about many aspects of Ottoman medicine, accompanied by another volume full of important archival documents in transcription. Many recent studies have consulted especially this second volume; see Coşkun Yılmaz and Necdet Yilmaz, eds., Osmanlılarda Sağllk=Health in the Ottomans, 2 vols. (Istanbul: Biofarma, 2006). Miri Shefer-Mossensohn worked on different components that made up Ottoman medicine such as Galenic medicine, folk medicine, and Prophetic medicine and their manifestation in practice at Ottoman medical institutions; see Miri Shefer-Mossensohn, Ottoman Medicine: Healing and Medical Institutions, 1500-1700 (Albany: SUNY Press, 2009). Natalia Bachour conducted meticulous research on lbn Sellum's works and his medical ideas that led the way to a new medical era in Ottoman medicine; see Natalia Bachour, Oswaldus Crollius und Daniel Sennert im frühneuzeitlichen Istanbul: Studien zur Rezeption des Paracelsismus im Werk des osmanischen Arztes Sälih b. Nasrullāh Ibn Sallūm al-Halabī (Freiburg: Centaurus, 2012). Innovative studies, such as those by Nükhet Varlık, indicate the need to include the Ottoman Empire in our discussions on global pandemics; see Nükhet Varlık, Plague and Empire in the Early Modern Mediterranean World: The Ottoman Experience, 1347-160o (New York: Cambridge University Press, 2015). There are also recent works on science and knowledge production in the early modern Ottoman world that also included medicine in their discussions, such as Harun Küçük, Science without Leisure: Practical Naturalism in Istanbul, 1660-1732 (Pittsburgh: University of Pittsburgh Press, 2020).

5 Here I am referring to all kinds of notes, but especially those that move beyond the tradition of writing commentaries and glosses on a medical text. In the medieval period, producing commentaries functioned as an important instrument for both learning sciences and contributing to the scholarship. However, we begin to see fewer of these examples in the medical domain for the works produced in the seventeenth- and eighteenth-century Ottoman world. On lslamicate commentaries in different scholarly genres, see the special issue of Oriens 41, no. 3/4, 2013, and especially on medical commentaries, see Nahyan Fancy, "Medical Commentaries: A Preliminary Examination of Ibn al-Nafis's Shurūh, the Mūjaz and Subsequent Commentaries on the Mūjaz," Oriens 41 (2013): 525-545. For a great collection of essays on European paratextual elements in medical manuscripts, see Hannah C. Tweed and Diane G. Scott, eds., Medical Paratexts from Medieval to Modern: Dissecting the Page (Cham: Palgrave Macmillan, 2018). 
dicine housed in the Istanbul Millet Library collection, I will show that readers of these two works could overlap and that they were willing to produce links between these two kinds of works via their manuscript notes. Like in many other early modern cultures, in the Ottoman context, too, the range of textual materials that were believed to promise therapeutic benefits were not restricted to prescriptive or pharmacological manuscripts. Apart from the difficulty of drawing boundaries between early modern genres, individuals in search of a cure for their ailments also made use of domestic recipes, prayers, amulets, etc., all of which are sometimes bundled together as simply non-scholarly medicine. ${ }^{6}$ Moreover, one finds that these seemingly disparate subfields can meet along with other medical cures in miscellanies (тестиа) and contribute to the wider healing domain. Especially in seventeenth- and eighteenth-century versions of these compilations, it is quite common to come across elements of these different categories brought together, where scholarly medical remedies stand side by side with other healing formulas.

\section{The Unique Gem on New Medicine}

The Unique Gem on New Medicine was produced in 1700 by the prominent physician of the eighteenth century Ömer Şifa'i.7 The text included translated parts from Ibn Sellum's (d. 1670) New Al/chemical Medicine (Kitab al-Tibb al-Jadid al-Kimya'i)-especially its introductory section-which was originally composed in Arabic, along with various recipes Şifa'i transcribed by relying on his knowledge and experience. Around the 166os, chief physician (hekimbaşı) Ibn Sellum's New Al/chemical Medicine introduced the field of iatrochemistry to Ottoman readership for the first time along with various new medical discussions. ${ }^{8}$ Iatrochemistry, or al/chemical medicine, was a medical trend that used alchemical philosophy and methodology to offer medical treatment. ${ }^{9}$ The foundations of

6 On popular medicine, see Roy Porter, ed., The Popularization of Medicine, 1650-1850 (London: Routledge, 1992); Margaret Healy, "Popular Medicine," in The Ashgate Research Companion to Popular Culture in Early Modern England, ed. Andrew Hadfield, Matthew Dimmock, and Abigail Shinn (Farnham: Ashgate Publishing Limited, 2014), 309-322; Elaine Yuen Tien Leong, Recipes and Everyday Knowledge: Medicine, Science, and the Household in Early Modern England (Chicago: University of Chicago Press, 2018); Mary Elizabeth Fissell, "Introduction: Women, Health, and Healing in Early Modern Europe," Bulletin of the History of Medicine 82, no. 1 (2008): 1-17; Edith Snook, “The Women Know': Children's Diseases, Recipes and Women's Knowledge in Early Modern Medical Publications," Social History of Medicine 30, no. 1 (2017): 1-21; and Mary Fissell, "Popular Medical Writing," in The Oxford History of Popular Print Culture, vol. 1, Cheap Print in Britain and Ireland to 1660, ed. Joad Raymond (Oxford University Press, 2011), 418-431. On medicine and magic, see Ofer Hadass, Medicine, Religion, and Magic in Early Stuart England: Richard Napier's Medical Practice (University Park: Penn State University Press, 2018); and Neil C. Hultin, "Medicine and Magic in the Eighteenth Century: The Diaries of James Woodforde," Journal of the History of Medicine and Allied Sciences 30, no. 4 (1975):349-366. As for the Ottoman context, in a recent work, Aslıhan Gürbüzel demonstrated how Sufi sheikhs could be part of the Ottoman healing world with their remedies as their disciples copied those advised cures and led to their dissemination among the people in need. See Sumeyra A. Gurbuzel, "Teachers of the Public, Advisors to the Sultan: Preachers and the Rise of a Political Public Sphere in Early Modern Istanbul (1600-1675)" (PhD diss., Harvard University, 2016), 225-265.

7 See Ömer Şifa'i, Cevherül-Ferid fi't-Tıbbil-Cedid, Süleymaniye Library, Nuruosmaniye 3498, 57b: "bin yüz on iki muharreminin evahirinde."

8 On the office of Ottoman chief physician, see M. Tayyib Gökbilgin, "Hekim-Bashi”" in Encyclopaedia of Islam, Second Edition, ed. P. Bearman, Th. Bianquis, C. E. Bosworth, E. van Donzel, and W. P. Heinrichs (Brill Online, 2012), accessed May 25, 2020, http://dx.doi.org.ezp-prodı.hul.harvard.edu/10.1163/1573-3912_islam_SIM_2849; Ali Haydar Bayat, Osmanlı Devleti’nde Hekimbaşılık Kurumu ve Hekimbaşılar (Ankara: Atatürk Kültür Merkezi Başkanlığı Yayınları, 1999). For more information on Ibn Sellum, see Miri Shefer, "An Ottoman Physician and His Social and Intellectual Milieu: The Case of Salih Bin Nasrallah Ibn Sallum," Studia Islamica 106, no. 1 (2011): 102-123. On the authorship of New Al/chemical Medicine, see Bachour, Oswaldus Crollius und Daniel Sennert, 107-134.

9 Throughout this paper, I will be using the words al/chemy and al/chemical to indicate that in early modern Islamicate sources, including Ottoman ones, the same Arabic word (i.e. kimya) was employed to refer to the whole field of chemical procedures independent of whether they would serve a transmutation operation of base metals into gold or not (e.g., distilling alcohol). As for the European context, several historians of science have employed the pre-modern term chymistry to reminds us that the distinction between alchemy and chemistry is a later phenomenon. As Lawrence Principe once noted, "Until about the end of the seventeenth century, the terms alchemy and chemistry were used largely interchangeably, and did not carry their modern definitions and distinctions. The division between the two terms dates from around 1700 , and is tied up with a number of issues, including the professionalization and institutionalization of chemistry at this time and the desire to insulate the newly professionalizing field from the criticisms to which earlier transmutational endeavors had been prone. Thus 'alchemy' then became equated with gold-making (and generally fraud), while 'chemistry' encompassed most everything else which could previously have been called either alchemy or chemistry. The important point is that it is distorting and historically inaccurate to read our current distinction between the terms back into the seventeenth century and earlier, and thus to imagine the existence of 'chemists' and 'alchemists' as distinct groups at that time." See Lawrence M. Principe, "Alchemy I: Introduction," in Dictionary of Gnosis \& Western Esotericism, ed. Wouter J. Hanegraaff (Leiden: Brill, 2006), 12-16. See also William Newman and Lawrence Principe, "Alchemy vs. Chemistry: The Etymological Origins of a Historiographic Mistake," Early Science and Medicine 3, no. 1 (1998), 32-65; Principe, The Aspiring Adept: Robert Boyle and His Alchemical Quest (Princeton: Princeton University Press, 1998), 8-10; Ku-ming Chang, "Alchemy As Studies of Life and Matter: Reconsidering the 
this medical approach can be traced to Theophrastus von Hohenheim, or Paracelsus (d. 1541), the Renaissance philosopher, alchemist, and physician who opposed Galenic doctrine in medicine and emphasized the importance of observation and experience. ${ }^{10}$ Against the Galenic understanding of viewing the health of the human body in terms of a balance among four humors (i.e., black bile, blood, yellow bile, phlegm), Paracelsus argued that there are actually three essential elements that can be found in the universe, and thereby also the human body: salt, sulfur, and mercury. Salt represented stability, sulfur combustibility, and mercury liquidity. While the Galenic approach required treatment by opposites, where for instance an excess of a cold humor should be treated with substances that would increase hot humors in the body, Paracelsus offered to cure diseases using the same element which he found to be lacking or in excess, paying close attention, notably, to the dosage of the medicine. ${ }^{11}$ Moreover, he contended that alchemy could offer new ways of producing remedies by using chemical methods such as distillation, sublimation, and precipitation, rather than relying on the Galenic therapeutic repertoire that was mostly herbal.

Ibn Sellum's New Al/chemical Medicine did not strictly follow a Paracelsian path. ${ }^{12}$ It included parts from Oswald Croll (d. 1609), an alchemist physician who was a strict follower of Paracelsus, as well as from Daniel Sennert (d. 1637), who "envisioned a reform of Galenist medicine and pharmacy that would be founded upon both chymistry and atomism."'13 New $\mathrm{Al} /$ chemical Medicine also consisted of the works of older physicians such as Johannes Jacob Wecker (d. 1586) and some recipes that harkened back the old Galenic medical framework. Ibn Sellum's work was thus eclectic, combining old and new, but especially emphasizing the importance of novel ideas and remedies to cure diseases. After New Al/chemical Medicine, $T \imath b b$ - $\iota$ cedid (new medicine) became a widely used concept among Ottoman physicians of the late seventeenth and eighteenth centuries in their titles and texts. This was a time when an awareness regarding the striking differences between the works of the ancients (mütekaddimun /kudema) and the contemporaries (müteahhirun) was developing in the medical domain. Physicians were willing to incorporate novel ideas and practices; however, they did not altogether abandon their old framework, which was mainly Galenic humoralism. ${ }^{14}$

One of those scholars who was willing to discover and make use of medical novelties was Ömer Şifa'i el-Bursevi. Although his epithet Bursevi gives the impression that he was originally from Bursa, the first capital of the Ottoman Empire, Şifa'i was actually born in Sinop, a northern city on the Black Sea coast of Anatolia. This is one of the few things

Place of Vitalism in Early Modern Chymistry," Isis 102, no. 2 (2011): 322-329; and William Newman, "From Alchemy to 'Chymistry," in The Cambridge History of Science Vol 3: Early Modern Science, ed. Katharine Park and Lorraine Daston (Cambridge: Cambridge University Press, 2006), 497-517.

10 For more information on Paracelsus, see Walter Pagel, Paracelsus: An Introduction to Philosophical Medicine in the Era of the Renaissance (Basel: Karger, 1982); and Paracelsus, Paracelsus (Theophrastus Bombastus von Hohenheim, 1493-1541): Essential Theoretical Writings, ed. Andrew Weeks (Leiden: Brill, 20o8). For recent discussions on Paracelsus, see the special issue of the Ambix: "Paracelsus, Forgeries and Transmutation," Ambix 67, no. 1 (2020).

11 Allen G. Debus, "The Philosophical and Medical Paracelsus: Paracelsianism and the Diffusion of the Chemical Philosophy in Early Modern Europe" in Paracelsus: The Man and His Reputation, His Ideas and Their Transformation, Studies in the History of Christian Thought, ed. Ole Peter Grell (Leiden: Brill, 1998), 225-244; Paracelsus, Paracelsus, 15-37; and Pagel, Paracelsus, 82-136.

12 For a detailed investigation of Ibn Sellum's works, its contents, and the sections adapted from European scholars, see Natalia Bachour, "Iatrochemistry and Paracelsism in the Ottoman Empire in the Sixteenth and Seventeenth Centuries," Intellectual History of the Islamicate World 6, no. 1/2 (2018): 82-116; Bachour, Oswaldus Crollius und Daniel Sennert. 13 Joel A. Klein, "Chymical Medicine, Corpuscularism, and Controversy: A Study of Daniel Sennert's Works and Letters" (PhD diss., Indiana University, 2014), 3. Although previous scholarship depicted Daniel Sennert as a Paracelsian, or as a mediator between the Galenists and the Paracelsians, Joel Klein demonstrates that "Sennert's experimental chymistry and atomism led him to adopt a new and controversial understanding of the humors, and it reinforced his belief that occult qualities or their so-called whole substance were responsible for many of the actions of medicine and diseases" (p. 44). In other words, "Sennert's medicine and philosophy were more radical in his own time than has been previously supposed" (p. 3). For earlier portrayals of Sennert, see Allen G. Debus, The Chemical Philosophy: Paracelsian Science and Medicine in the Sixteenth and Seventeenth Centuries, Volume I (New York: Science History Publications, 1977), 191-204; Walter Pagel, The Smiling Spleen: Paracelsianism in Storm and Stress (Basel: Karger, 1984), 86-91; Emilie Savage-Smith, “Drug Therapy of Eye Diseases in Seventeenth-Century Islamic Medicine: The Influence of the 'New Chemistry' of the Paracelsians," Pharmacy in History 29, no. 1 (1987): 7; and Peter E. Pormann and Emilie Savage-Smith, Medieval Islamic Medicine (Edinburgh: Edinburgh University Press, 2007), 171. On Oswald Croll, see Hiro Hirai, "The Word of God and the Universal Medicine in the Chemical Philosophy of Oswald Croll," in Alchemy and Rudolf Il: Exploring the Secrets of Nature in Central Europe in the 16th and 17th Centuries, ed. lvo Purš and Vladimír Karpenko (Praha: Artefactum, 2016), 381-385. 14 See Akif Ercihan Yerlioğlu, "Paracelsus Goes East: Ottoman 'New Medicine' and its Afterlife" (PhD diss., Harvard University, 2020). 
about Şifa'i's life that biographical sources unanimously agree upon; however, the rest can be quite confusing. From his own words, we know that he traveled a lot, and it was during one of these travels, on his return from Mecca, that he met his spiritual guide, Sheikh Hasan el-Halveti and decided to quit traveling and spend some time with the sheikh for his spiritual development. ${ }^{15}$ These travels probably helped him meet other scholars from diverse fields and learn from them. Şifa'i was interested in both medicine and alchemy and enjoyed using alchemical allegories in his writing. Being a successful physician, he made his way to serve as the head physician of the sultanic hospital in Bursa, Bayezid Hospital (darüş̧̧ifa).

There are many extant copies of Ömer Şifa'i's The Unique Gem in the manuscript libraries in and outside of Turkey. ${ }^{16}$ Considering the popularity of his other works in addition to this one, it is easy to deduce that he was one of the most prominent and widely read medical scholars of the eighteenth century. The fact that other physicians of the period noted that they read and consulted Şifa'i's works before producing their own demonstrates the significance of his place in Ottoman medical literature. ${ }^{17}$ One should also consider that this influence was bolstered through his students, who always revered him in their works, leading to his further prominence in the medical field. Şifa'i trained two physicians, Ali Münşi (d. 1733) and Abbas Vesim (d. 1760), who would become leading scholars of their time with their prominent works. ${ }^{18}$

One of the copies of Şifa'i's The Unique Gem is kept at the Millet Library with the catalog code Ali Emiri Tib 77 (hereafter AE). In this manuscript, before the main text, there is a long note written in a different hand about an al/chemical experiment, which appears to be taken from another source. This excerpt continues at the very end of the manuscript, where the main text ends. Nowhere in the manuscript is there any information about the copyist of the whole text nor about the reader who inserted this separate passage. However, those who are familiar with widely circulated popular texts from the late eighteenth century would recognize these lines as an excerpt from Nusret Efendi's What Medicine Entails (Ma Hazara fit-Tibb), a collection of medical remedies, as well as spiritual and magical healing solutions. ${ }^{19}$ It seems that Nusret Efendi's wish towards the end of his report of the abovementioned procedure, "May those who understand what I wrote remember this humble one," was granted at the hands of the AE's reader when he reproduced these lines-though he did not put the name of the author. ${ }^{20}$

15 See Necdet Okumuş, "Ömer Şifâî Efendi," in TDV İslam Ansiklopedisi (Istanbul: Türkiye Diyanet Vakfı, 20o7), 34:82-83. Ömer Şifa’i, Mürşidü'l-Muhtar, Süleymaniye Library, Halet Efendi 753, 3a; Ömer Şifa’i, Şifa'ü’l-Eskam, Cerrahpaşa Tip Fakültesi, Institute of Medical History, 1195 (old no. 595), 4a-4b.

16 Ekmeleddin İhsanoğlu and his colleagues recorded twenty-five copies in total; see Ekmeleddin ihsanoğlu et al., eds., Osmanlı tıbbi bilimler literatürü tarihi = History of the literature of medical sciences during the Ottoman period (Istanbul: İslam Tarih, Sanat ve Kültür Araştırma Merkezi IRCICA, 2008), 365-366.

17 See, e.g., Gevrekzade Hafiz Hasan, Nikris Risalesi, Topkapı Palace Museum Library, H. 564, 28a.

18 On 'Ali Münşi, see Feridun Nafiz Uzluk, "Bursalı Hekim Ali Münşi Efendi," D.T.C.F. Dergisi 7 (1950): 329-337; and Arslan Terzioğlu, "Ali Münşî," in TDV İslâm Ansiklopedisi (Istanbul: Türkiye Diyanet Vakf1, 1988), 2:421-422. On Abbas Vesim, see Cahit Baltacı, "Abbas Vesim Efendi," in TDV İslam Ansiklopedisi (Istanbul: Türkiye Diyanet Vakf1, 1988), 1:29-30; and Ibrahim Halil Tŭğluk, "Abbas Vesîm Efendi; Hayatı, Eserleri, Edebî Kişiliği, Divanı'nın Tenkitli Metni ve İncelemesi" (PhD diss., Gazi Üniversitesi, 2007).

19 This latter group is sometimes labeled as 'ilm el-havas, or havas ilmi in the Ottoman context. For more information on the issue, see ilyas Çelebi, "Havas Illmi," in TDV Islam Ansiklopedisi (lstanbul: Türkiye Diyanet Vakf1, 1997) 16:517-521. There are more than hundred copies of What Medicine Entails, both in manuscript and print formats. One can notice significant divergences in the contents of these different copies. Some of them might even include parts added later by the readers, which eventually made their way to the print copies. Hence, a critical edition of the work is needed, but unfortunately has not been produced hitherto. However, there are two recent MA theses that have investigated What Medicine Entails. Şule Yüksel Özkaya relied on a nineteenth-century manuscript housed at Süleymaniye Library (Halet Efendi 744), whereas Serkan Çinar worked on a printed version, of which he provided a facsimile appended to his thesis. Content discrepancies-including very critical ones-can be detected in these two copies, as well. There are also available digital versions of the text on internet sources such as Hathi Trust. Nonetheless, most of these copies do not have definite information regarding the year they were printed and the name of the printing presses, which makes it difficult to use citations from them. Hence, throughout this paper, I will be consulting these two theses mentioned above, relying on their own transcriptions provided there, when I need to give direct citations from What Medicine Entails. See Şule Yüksel Özkaya, "Bir XIll. Yüzyıl Müellifi Ebû Bekir Nusret Efendi'nin 'Mâ-Hazara Fi't-Tıbbı'r-Rûhâni ve'l-Cismâni’ Adlı Eserinin İncelenmesi ve Transkripsiyonu” (master's thesis, Marmara Üniversitesi, 2017); and Serkan Çınar, "Ebubekir Nusret Efendi'nin Risale-i Nusret Efendi Adlı Eseri (İnceleme-Metin-Dizin)" (master's thesis, Karabük Üniversitesi, 2019).

2o Özkaya, "Bir XIll. Yüzyıl Müellifi,” 7o: "ne yazdığımı fehm idüp bu fakiri yâd eyleye." 
We know little about Nusret Efendi's life. He was born in Harput, a city in eastern Anatolia, where he also completed his primary education. Nusret Efendi became interested in Sufism and literature in Persian, Arabic, and Turkish. At some point, he came to Istanbul and acquired fame as one of the best Persian tutors of his time..$^{21}$ Nusret Efendi first served as the head librarian of Süleymaniye Library, then Nuruosmaniye Library for a long while. ${ }^{22}$ Also a renowned poet, he produced a collection of poetry (divan) and many commentaries as well. ${ }^{23}$ However, the only work he composed on medicine and healing is What Medicine Entails. Biographical sources are confusing in terms of determining the year of his death. Even though some have indicated that he died in 1795, the poet Sururi's (d. 1814) chronogram about the passing of Nusret Efendi reveals the hijri date 1208, corresponding to 1793/1794. ${ }^{24}$

While introducing What Medicine Entails, Nusret Efendi explained that his work was comprised of two parts. The first part included cures that he knew through his own experience (tecribe/tecrübe), whereas the second part was a meticulous compilation of those that were labeled as "tested-and-true" (mücerreb) in the works of physicians. ${ }^{25}$ Throughout the text, Nusret Efendi specifically underlined whether he could observe the expected effects of a medical procedure or failed to obtain fruitful results. ${ }^{26}$ Moreover, he indicated whether he tried the treatment in question many times - "maybe a thousand times" ("belki bin kerre tecribe eyledim")-and found it successful. ${ }^{27}$ The author even invited sceptics who would question the effectiveness of some of his remedies to experiment by themselves: "Those who have doubts can go ahead and test it" ("Şübhesi olan tecribe buyursun"). ${ }^{28}$ Expressions like "experience" or "tested-and-true" were not random words used by the author. The prominent medical works of the earlier century, especially those influenced by $\mathrm{al} / \mathrm{chemical}$ medicine, had already underlined the importance of experience. In addition, the period Nusret Efendi lived in witnessed the substantial increase in individual recipe collections as well as the practice of recording recipes as marginalia in a variety of genres. ${ }^{29}$ This phenomenon went hand in hand with the rise of miscellanies in the seventeenth century, which continued during the eighteenth century. ${ }^{30}$ It is worthwhile to emphasize that Nusret Efendi himself calls his work a "miscellany" (тестиа) more than once. Here, we can use Nusret Efendi's own words to portray the abundance of available recipes: "Physicians prescribe five hundred remedies for a malady" ("bir illete etıbba beş yüz ilac yazarlar"). ${ }^{31}$ This was mainly due to the dominant Galenic understanding of the patient's complexion as unique and individual while offering a treatment. Moreover, every patient lived in different circumstances, another set of factors that the physician took into account,

21 Emîn Efendi, Osmanlı hayatından kesitler: Menâkıb-ı Kethüdâzâde el-Hac Mehmed Ârif Efendi, ed. Hasan Gürkan and Hür Mahmut Yücer (Istanbul: İnsan Yayınları, 2007), 168.

22 Çınar, "Ebubekir Nusret Efendi," 114: "süleymaniyyede hafız-1 kütüb iken." Some of the previous works failed to notice that Nusret Efendi reported in What Medicine Entails that he had been the librarian of Süleymaniye Library before taking the position at Nuruosmaniye. See, e.g., Mehmet Süreyya, Sicill-i Osmanî, ed. Nuri Akbayar and Seyit Ali Kahraman (Istanbul: Kültür Bakanlığı, Türkiye Ekonomik ve Toplumsal Tarih Vakfı, 1996), 1278.

23 On Ebubekir Nusret Efendi’s poetry, see Gökhan Alp, "Ebûbekir Nusret Efendi Dîvânı" (master's thesis, Kırıkkale Üniversitesi, 2015); and Kemal Karabuçak, "Ebubekir Nusret Divânı (İnceleme-Tenkitli Metin)" (PhD diss., Sakarya Üniversitesi, 2018). On Nusret Efendi's commentaries, see Hüseyin Gönel, "Nusret Ebubekir Efendi ve Sầib Serhi Üzerine Bazı Notlar," Turkish Studies 4, no. 6 (2009): 193-212; and Osman Ünlü, "Ebubekir Nusret'in Sâib-i Tebrizî Şerhleri," Turkish Studies 4, no. 6 (2009): 442-455.

24 Fatîn Davud, Hâtimetüll-Eşấr (Fatîn Tezkiresi), ed. Ömer Çiftçi (T.C. Kültür ve Turizm Bakanlığı Kütüphaneler ve Yayımlar Genel Müdürlüğü, 2013), 406.

25 Çınar, "Ebubekir Nusret Efendi," 85: "bu mecmua cem" eyledigim iki kısımdan ibaretdir biri kendim tecrübe eyledigim eşyalardır biri dahi kütüb-i etibbada mücerreb ve sahihdir deyü yazdıklarından hüsn-i zann ile ve imán-ı fikr ile istihsan itdigim menafílerdir."

26 Here are some of the expressions Nusret Efendi used throughout the text: "Lakin fakir tecribesine muvaffak olamadım." "Gördüm lakin tecribe etmedim." "Amma fakir tecribe idemedim" "Kendim de tecribe etmissimdir." "ikisini dahi tecribe eyledim, sahihdir" "Fakir dahi bir kerre tecribe eyledim; isabet eyledi”; see Özkaya, "Bir XIIl. Yüzyll Müellifi," $55,74,77,83,95,96$

27 lbid., 81.

28 lbid., 57 .

29 On the growing use of recipes in the early modern Ottoman medical market, see Küçük, Science without Leisure, 143-166.

30 On the importance of miscellanies and the range of their contents, see the edited volume, Hatice Aynur et al., eds., Mecmûa: Osmanlı Edebiyatının Kırkambarl (Istanbul: Turkuaz, 2011).

31 Çınar, "Ebubekir Nusret Efendi," 85. 
leading eventually to different remedies for the same ailment. Apart from these dimensions, according to Nusret Efendi, some physicians also kept some useful knowledge about drugs only to themselves. ${ }^{32}$ That is why he wanted to share some of those beneficial formulas with his readers, relying on both his learning from books and his hands-on experience.

If we are to use an anachronistic category, we can deem Nusret Efendi's work an early modern "self-help" book. In terms of how one should approach his text for treatment, this was what Nusret Efendi recommended: "For those who are inclined to use one of the singles or compounds in this miscellany, it is advisable to consult a physician and ask, 'I have found this cure for my ailment. Is it proper or harmful?"'33 Even though parts of his work reveal that he had some visitors, or "patients" if you will, who asked for his advice, Nusret Efendi knew he might be targeted by his competitors, especially those with a legitimate medical diploma or permission. ${ }^{34}$ As a way to fend them off, he found it safer to note that the patient should go and discuss the remedy in the text with a physician instead of relying on his recommendations alone.

How did Nusret Efendi acquire his medical experience? It seems that most of it came from self-study, accompanied by his own experiments. Nusret Efendi, in fact, indicated quite frankly in his introduction that he did not receive any medical training from any expert physician ("bu fakir bir üstad-1 kamil tabibe hizmet itmedim"). 35 He seems to be quite aware that learning from a master physician was an essential part of medical training, especially its practical (ameli) dimensions. ${ }^{36}$ On the other hand, Nusret Efendi assured his readers that he closely studied all the significant remedies recorded in the books of the prominent physicians in three languages (i.e. Arabic, Persian, and Turkish) ("kütüb-i etıbbada elsine-i selase üzerine mevcud olanlarına mütalaa"). Among the works of eminent scholars that he consulted, Nusret Efendi mentions Ibn Sina (Avicenna) (d. 1037), who had been among the main authorities for theoretical Islamic medicine. Moreover, especially for the use of pharmaceutical materials, Nusret Efendi cites Ibn al-Baytar (d. 1248), the Andalusian physician and pharmacist widely known for his pharmacopeia Compilation of Simple Drugs and Food (al-Jami' li-Mufradat alAdwiya wa'-Aghdhiya). There were abridged versions and Turkish translations of this work, which rendered it a fundamental reference book for the practitioners of the Islamicate world. Nusret Efendi also indicates that he consulted Davud el-Antaki's (d. 1599) works, another set of sources celebrated by Ottoman medical scholars. Last but not least, the author also benefited from Emir Çelebi's (d. 1638) books. The seventeenth-century Ottoman scholar, Emir Çelebi, served as the chief physician to Murad IV (r. 1623-1640) and produced medical works that circulated within the borders of the empire, many copies of which are still in manuscript libraries..$^{37}$ At this point, remembering Nusret Efendi's profession might help us acknowledge the opportunities he had to accumulate an abundance of knowledge in different areas. As the head librarian of one of the prominent libraries of Istanbul, Nusret Efendi had access to books from almost all genres: medicine, Sufism, and alchemy, just to name a few. As the diversity of the formulas recorded in his text reveals, he was interested in the field of healing in its broadest sense. Eventually, he would also view his collection of cures as a "gift" to the world of libraries ("vedi'a-i kitabhane-i alem itmek iktiza eyledi"). ${ }^{38}$

Was Nusret Efendi aware of Ömer Şifa'i’'s works as well? I believe he was. As for his own experimentation, we see that Nusret Efendi's trials also involved al/chemical methods. Even though alchemy is commonly-and almost exclusively-associated with transmutation

\footnotetext{
32 Ibid.: "etıbbanın cümlesi bu hususu ketm iderler ve sadırlarında ahirete götürürler ve ahiretde bunların fa'idesin olmadıgını gördükden sonra dünyaya bir dahi gelseler yine söylemezler."

33 Ibid.: "bu mecmuadan bir müfredin ya bir mürekkebin istimaline meyl idenler münasib olan etibbadan biriyle müşavere idüb benim şu illetime böyle bir ilac buldum münasib midür yahud bir zararı var mıdur deyü su’al itmekdür." 34 See, for instance, Özkaya, "Bir XIll. Yüzyıl Müellifi,” 83, 87, 88; Çınar, “Ebubekir Nusret Efendi," 103, 114-115, 122. 35 Çinar, "Ebubekir Nusret Efendi," 85.

36 Sixteenth-century physician Nida'i earlier indicated that "serving a master [physician]" is one of the requirements of becoming a physician: "Tabib olana birkaç nesne lazım / Buları bilmege ola mülazım / Biri üstada hizmet eylemekdür / Emekdür evveli sonra yimekdür"; see Ahmet Acıduman, "Ankaralı Hekim Nidầî ve Ünlü Eseri Menâfi'ü’n-Nas: XVI. Yüzyıldan Çocuk Hastalıkları ve Tıbbî Deontolojiye Bir Bakış," Çocuk Sağlığı ve Hastalıkları Dergisi, no. 56 (2013): $163-164$. 37 ihsanoğlu et al., Osmanlı tıbbi bilimler, 232-238.

38 Çınar, "Ebubekir Nusret Efendi," 85; Özkaya, "Bir XIll. Yüzyıl Müellifi," 41: "vedî́a-i kitâbhâne-i âlem itmek ilham olundi."
} 
of base metals into gold, or chrysopoeia, some early modern alchemists were also engaged in applying their knowledge and practice to produce dyes, perfumes, or drugs. Some alchemists believed that as a result of their alchemical quests, they could offer the elixir, or panacea, that could heal all diseases. ${ }^{39}$ Since none of Paracelsus's works were translated in their entirety, Ottoman readers learned about Paracelsus and his followers-and their al/ chemical propositions-from the renderings of physicians such as Ibn Sellum and Ömer Şifa'i. And contents of Nusret Efendi's What Medicine Entails reveal that he knew about Paracelsian recipes and was eager to try some of them. Even though the author mentioned Ibn Sellum, but not Ömer Şifa'i, in his work, it is highly probable that he also read the works of the latter. ${ }^{40}$ Moreover, among the rich collection of Nuruosmaniye Library, where Nusret Efendi was employed, we know that there are at least two extant copies of Ömer Şifa'i's prominent work, The Unique Gem. ${ }^{41}$

\section{The Unique Gem, the AE Copy}

Nusret Efendi's interest in Paracelsus and Paracelsian remedies takes us to the main focus of this article: the manuscript notes in the AE copy of Ömer Şifa'i's The Unique Gem. This part is written in a strikingly different hand than the main text. Without any title, a two foliolong description of an al/chemical process was recorded: producing "gold oil" (altun yağı) following an alleged Paracelsian method. The same detailed account is also found in Nusret Efendi's What Medicine Entails. That is to say, a reader of the AE apparently recorded Nusret Efendi's lines about how to prepare this al/chemical recipe. In this passage, Nusret Efendi explains that there are a few methods to produce this material; however, an alchemist should pay great attention to its preparation. Nusret Efendi's description corresponds to aurum potabile, or potable gold, which has been a matter of discussion in the alchemical literature. Even before Paracelsus, alchemists

endeavored to extract a "tincture" from gold that contained all the metal's characteristic color, leaving behind an anomalous white metal. Chymists considered this tincture the separated Sulfur of gold, sometimes called the anima auri, or "soul" of gold. This tincture was then to be used to "tinge" a white metal into gold. Some considered this material the sought-after potable gold, a powerful liquid medicineperhaps a universal panacea-supposedly prepared from gold..$^{42}$

This is a great example that presents the liminal area between alchemy and medicine, since the end product of the formula in question is believed to cause mildness on the disposition of the person who consumes it, among many more benefits than expected. ${ }^{43}$

Although we cannot be sure about the dating of the manuscript note, its style makes one think that it might be from the eighteenth century. Even if it is recorded at a later time, it still serves our point here on the blending of boundaries between scholarly curative formulas and those prescriptions that sometimes embrace spiritual, alchemical, and magical remedies. Nusret Efendi's interest in Paracelsus in the late eighteenth century demonstrates that the Swiss physician was still revered highly in this era, when his name and thoughts had almost disappeared in scholarly discussions taking place in Europe. First introduced in the seventeenth century with the advent of iatrochemical works mostly in Turkish, Paracelsian ideas apparently circulated among not only physicians but also others who did not go through a medical educational path.

39 Bernard D. Haage, "Alchemy ll: Antiquity-12th Century," in Dictionary of Gnosis \& Western Esotericism, ed. Wouter J. Hanegraaff (Leiden: Brill, 20o6), 16-34. 40 Özkaya, "Bir XIII. Yüzyıl Müellifi," 78.

41 All the books of Nuruosmaniye collection are now kept at Süleymaniye Library; see Ömer Şifa'i, Cevherü’l-Ferid fi't-Tıbbi'l-Cedid, Süleymaniye Library, Nuruosmaniye 3497 and 3498. The latter manuscript also has its date of copying: hijri 1150, which corresponds to 1738 . If the manuscript became part of the library collection not so long after its reproduction, it is highly probable that Nusret Efendi was still there and had seen this copy.

42 Lawrence Principe, The Secrets of Alchemy (Chicago: University of Chicago Press, 2013), 113.

43 Özkaya, "Bir XIIl. Yüzyıl Müellifi," 68: "bu altundan ekl idenin elbette mizacına itidal sirayet ider." 
In this section, Nusret Efendi indicates that he tried and experimented with one of the recipes of Paracelsus. Then, almost in a complaining tone, he notes, "Paracelsus whitened sulfur by using salt of tartar, yet exaggerated its advantage in his writing. This humble one was also passionate about replicating it; however, I could never observe its benefit." 44 So, what Nusret Efendi did was tweak the formula and share his own method with his readers. However, there were a lot of issues to keep in mind, according to the author. First of all, he had consulted many other alchemical figures such as the Seljukid vizier and alchemist Mu'ayyad al-din al-Tughra'i (d. 1121), the Andalusian alchemist Abu'l Hasan Ali ibn Musa Ibn Arfa' Ra's (d. 1197), and the Greek alchemist Balinas, or Apollonius of Tyana (d. ca. 100 $\mathrm{CE}$ ), and realized that only two types of medication with gold were found appropriate for consumption. This was a dangerous procedure, which became obvious from Nusret Efendi's statements that he witnessed a lot of people's death as a result of consuming gold. 45

Can we view the preference of the AE's owner to record this entire note just before Ömer Şifa'i's text on iatrochemistry or al/chemical medicine as purely coincidental? In other words, among all of Nusret Efendi's prescriptions, can we regard this particular Paracelsian recipe, written prior to The Unique Gem, as unrelated? My answer is negative. On the contrary, I contend that this excerpt inserted to an influential medical text of the period hints at the correspondence between alchemical and medical literatures in the Ottoman Empire, both for their authors and readers.

We should acknowledge that there was affinity between alchemy and medicine, apparent from how Ottoman libraries-especially their catalogues-were arranged. Deeply interested in Ottoman scholarly productions, Venetian priest Giambattista Toderini (d. 1799), who visited Istanbul in 1781-1782, noted his observations on the libraries of Istanbul in his work De La Littérature Des Turcs. One can imagine that Toderini might have seen or even met Nusret Efendi when he spent some time at the Nuruosmaniye Library. As Toderini was browsing through the collection of the Atıf Efendi Library, he indicated that there was no individual section for alchemy (chimie) in this repository. Books on alchemy were mixed with those on medicine, while there was a separate alchemy section at the Nuruosmaniye Library ${ }^{46}$ Besides underlining this taxonomical closeness, he also stated, in more than one section, that there were many Ottomans interested in alchemy, some of whom were also practicing medicine.

Before delving into the relationship between the two fields further, we should clarify that views on alchemy, especially transmutation practices, were far from unanimous among early modern scholars. Some cherished it, while the others condemned it. Awareness of this latter attitude might be one of the reasons why physicians strove to justify the fact that in their attempts to make al/chemical recipes to preserve one's health, or spagyria

44 Idib., 69: "Berakilos, milh-i tartar ile bir kibrit tebyiz idüp menafiinde mübalağa hassalar tecribe etmiş. Fakir dahi tama idüp istimal eyledim, bir dürlü nef ini müşahede idemedim.” Since Özkaya does not provide a facsimile of the manuscript she worked on, how the name of Paracelsus was rendered is not clear; however, the reader who copied this section to the AE preferred a version which is more in line with other medical texts of the period: Baraklisus or (بركلسوس). This section does not appear in the copy that Çınar worked on. In al/chemical literature, tartar referred to "either the material which collected on the inside of wine barrels, or a more complex substance or group of substances that was merely analogous to common tartar," and it has been widely used in al/chemical practices; see Klein, "Chymical Medicine, Corpuscularism, and Controversy," 46. Salt ofz tartar (milh-i tartir/tartar) corresponds to potassium carbonate, which was obtained by calcination of potassium bitartrate; see George Starkey, Alchemical Laboratory Notebooks and Correspondence, ed. William Royall Newman and Lawrence Principe (Chicago: University of Chicago Press, 2004 ), 344. Apart from its use in al/chemical recipes, Paracelsus placed special emphasis on tartar also in his theory of illness as a disease-causing agent. In his writings, "tartar could be a calculus, or stone, in the body, or it could refer to any number of bodily changes brought about by the obstructions associated with the heart, lungs, spleen, kidneys, or brain"; see Bruce T. Moran, Distilling Knowledge: Alchemy, Chemistry, and the Scientific Revolution (Cambridge, MA: Harvard University Press, 2005), 78. Paracelsus pointed out that "because it [tartar] was volatile it could easily travel throughout the body, entering various organs, and its salty nature meant that it coagulated in various places throughout the body, leading to diverse ill effects, ranging from gout and arthritis to sciatica and kidney"; see Klein, "Chymical Medicine, Corpuscularism, and Controversy," 46-47 (brackets mine). Whitening (tebyiz) is one of the basic steps in alchemical processes in which colors of base metals are turned into white, resembling silver; see Tuna Artun, "Hearts of Gold and Silver: The Production of Alchemical Knowledge in the Early Modern Ottoman World" (PhD diss., Princeton University, 2013 ), 78. 45 Özkaya, "Bir XIll. Yüzyıl Müellifi," 68-69: "Lâkin âdem bilürüm, zehebür'r-ra'd [sic.] isti'mâliyle helâk oldılar. Bu sebebden indimizde bulundığı rütbe tenbîh eyledik."

46 Giambattista Toderini, De la littérature des Turcs, Tome Second, trans. Antoine de Cournand (Paris: Chez Poinçot, Libraire, rue de la Harpe, no. 135, 1789), 88, 97. 
as Paracelsians coined it. For instance, while Ömer Şifa'i was explaining the purpose of utilizing al/chemical methods, he noted two aspects: "The first part has to do with the perfection of base metals and transformation of forms to more noble ones. The second part is about preservation of the current health and prevention of its loss." ${ }^{77}$ Müderris Hasan Efendi, another contemporary physician of Ömer Şifa'i, put it in a straightforward way in the introductory section of his own translation of New Al/chemical Medicine, entitled Utmost Limit on Treatment of the Sick (Gayetü'l-Münteha fi Tedbiril-Merza): "This is the book of new medicine and it belongs to [the field of] alchemy (kimya). New medicine was invented by the physician named Paracelsus." ${ }^{48}$ As a representative example of an Ottoman intellectual who did not have a high opinion about the art of alchemy in general, we may turn to the celebrated early modern scholar Kâtip Çelebi (d. 1657). In his Memorandum (Fezleke), Kâtip Çelebi used sharp comments about those who were interested in alchemy. For instance, while talking about el-Mevla Mehemmed (d. 1607), who once served as the qadi of Konya (in 1602/1603) among other offices, the author underlined that el-Mevla Mehemmed was engaged in alchemy and also produced some texts on the subject. Then, Kâtip Çelebi continued with his take on alchemical textual productions: "Truly, this type of composition is [nothing but] a deceitful trap for the ignorant and fetters for the fool." ${ }^{\prime 9}$ Even though Kâtip Çelebi was not alone in his censure against alchemy, it is difficult to generalize this attitude to each and every dimension of society. The palace library, on the contrary, seems to have acquired a lot of books on various arts and sciences, including alchemy. ${ }^{50}$ Apart from those readers of alchemy who visited the libraries of Istanbul-some of which were mentioned above-there were apparently others who had access to the most prestigious book depository of the empire.

As for the authors who included iatrochemical discussions in their works, they were already aware of the alchemical tradition in the Ottoman and the larger Islamicate world, and at times alluded to that literature. ${ }^{51}$ We know, for instance, that Ömer Şifa'i was quite familiar with alchemical works in general and figures like the widely read Eşrefzade Ali Çelebi (d. 1609) in particular..$^{52}$ In fact, Ömer Şifa'i's work The Guide of the Elect in the Science of Secrets (Mürşidü'l-Muhtar fi 'ilmi'l-Esrar) comprised references to old alchemists as well as recent ones like 'Ali Çelebi, who was also known as the "new author" (mü'ellif-i cedid)..$^{53}$

More importantly, Ömer Şifa'i's readers seem to be conscious of these connections and scholarly lineages, as well. A late eighteenth- or early nineteenth-century miscellany kept at Istanbul University's Library of Rare Books and Manuscripts can tell us more about these links. Bringing together short treatises or sections from medieval alchemical scholars, the manuscript also includes the epilogue of The Guide of the Elect by Ömer Şifa'i. The compiler elaborately brought together pieces from prominent alchemists such as al-jildaki (d. 1342) and Ibn Hayyan (or Geber) (d. ca. 815). Thus, that a selection of Şifa'i appeared among them is not at all accidental. ${ }^{54}$

47 Ömer Şifa'i, Cevherü'l-Ferid fi't-Tıbbı'l-Cedid, Süleymaniye Library, Hamidiye 102o, 3b: "bu ilmin gayeti iki kısma münkasımdur kısm-ı evvel ma‘den-i nakısayı tekmil ve suverlerin suver-i eşrefiye tebdil kılmakdur kısm-1 sani hıfz-1 sihhat-i mevcude ve redd-i sıhhat-i mefkudedür."

48 Müderris Hasan Efendi, Gayetü’l-Münteha fi Tedbirill-Merza, Süleymaniye Library, Tahir Ağa Tekke 395, 3a: "bu kitab tıbb-1 cedid kitabıdur ve kimyaya mensubdur ve bu tıbb-1 cedidi brasula didikleri hekim çıkarub peyda itmişlerdür." This manuscript is also known and catalogued as Gayetül-Müna fi Tedbiri'l-Merza /Maraz.

49 See Zeynep Aycibin, "Kâtib Çelebi, Fezleke, Tahlil ve Metin" (PhD diss., Mimar Sinan Güzel Sanatlar Üniversitesi, 2007), 541-542: "Fi'l-hakika ol makule te'lifat dam-1 tezvir-i nadan ve pa-bend-i ahmakandır."

50 See Noah Gardiner, "Books on Occult Sciences," in Treasures of Knowledge: An Inventory of the Ottoman Palace Library (1502/3-1503/4), ed. Gülru Necipoğlu, Cemal Kafadar, and Cornell H. Fleischer (Leiden: Brill, 2019), 735-765. See also Jan Schmidt, "The Occult Sciences and Their Importance in Ottoman Culture; Evidence from Turkish Manuscripts in Dutch Public Collections," Osmanlı Arastırmaları 23 (2003): 219-254. For a recent re-evaluation of the occult sciences in Islamicate societies, see the special issue, "Islamicate Occultism: New Perspectives," ed. Matthew Melvin-Koushki and Noah Gardiner, Arabica 64 (2017): 287-693.

51 See Feza Günergun, "Convergences in and around Bursa: Sufism, Alchemy, latrochemistry in Turkey, 1500-1750," in Entangled ltineraries: Materials, Practices, and Knowledges across Eurasia, ed. Pamela H. Smith (Pittsburgh: University of Pittsburgh Press, 2019), 227-257.

52 For more information on Eşrefzade Ali Çelebi, see Tuna Artun, "Hearts of Gold and Silver." See also İhsan Fazlıŏlu, Fazıl Ali Bey [Ali El-íznikî], accessed April 29, 2020, http://fazlioglu.blogspot.com/2018/o7/prof-dr-ihsan-fazlioglu-fazil-ali-bey-ali-el-izniki.html; and Merve Nur Gür, “Ali El-İznikînnin 'Cevahir El-Esrar Fî Ma'arif El-Ahcar' Adlı Eserinin Çeviri ve İncelemesi” (master’s thesis, Fatih Sultan Mehmet Vakıf Üniversitesi, 2016).

53 See Ayten Aydın, "Ömer Şifaî̀nin Mürşid El-Muhtar Fî İlm El-Esrâr Adlı Eserinde Simya," Ankara Üniversitesi Osmanlı Tarihi Araştırma ve Uygulama Merkezi Dergisi 17 (2015): 1-11.

54 See Ömer Şifa’i, Mürşidü’l-Muhtar Fi 'ilmi'l-Esrar, Istanbul University Rare Books and Manuscripts Library, T. 9314. 
The AE manuscript, which brings together Ömer Şifa'i and Ebubekir Nusret Efendi, seems not to be a rare case. Tekelioğlu 920 copy of Summary of Bodies (Hulasatü'l-Ebdan), another work by Ömer Şifa'i, housed at Süleymaniye Library, was bound along with Nusret Efendi's What Medicine Entails. ${ }^{55}$ This time, we are not talking about the insertion of a short passage, but the text in and of itself-albeit with some missing parts. I believe there are more examples in manuscript libraries that allow for the blending of genres in the field of healing. However, a thorough research is needed to figure out these entanglements along with paratextual traces of their readers.

\section{More Manuscripts, More Questions}

Regarding reading practices, we should admit that we have less information on who actually read medical books and how, compared to what was read in early modern period. Previous studies increased our knowledge about which books were consumed, but they have mostly concentrated on institutional learning of medicine. The medical curricula of Ottoman madrasas before the seventeenth century gives us an idea about the books that circulated among the students. ${ }^{56}$ Textual sources that chief physicians used for teaching purposes similarly shed light on medical learning. ${ }^{57}$ In addition, recent works on the palace library also present what the most prestigious repository of the empire acquired for its medicine section..$^{8}$ The works of Hippocrates (d. ca. 370 BCE), Galen (d. ca. 216), Abu Bakr Muhammad b. Zakariyya al-Razi (d. ca. 925), Ibn Sina, Jalal al-Din Khidr b. Ali (or Hacı Paşa) (d. ca. 1425), and others, which may be regarded as classics of medical learning, could be found in these catalogues. ${ }^{59}$ However, at the turn of the seventeenth century, the picture gets more complicated with the translation of new works from European medical sources into Ottoman Turkish. ${ }^{60}$ These texts did not immediately become part of medical learning, yet allured anyone who is interested in medicine and new al/chemical methodologies beyond institutional affiliations. Hence, our discussion here includes-though is not restricted tothe world outside these institutions and highest ranks of society: authors who were not products of the standard medical learning path, like Nusret Efendi, and readers who wanted to know about both The Unique Gem and What Medicine Entails, which could hardly have been part of the standard medical curriculum.

To generate more questions on early modern medical manuscripts, their readers, and healing culture, I will provide one last manuscript example before I conclude my discussion. Not surprisingly, Ömer Şifa'i, as one of the most important physicians of the period, will again take part in this case. Let us now turn to another eighteenth-century medical work: Summary of Medicine (Hulasatü't-Tıbb) by Ebu'l-feyz Mustafa (d.ca.1750), a prominent scholar who was the head physician of the Sultan Ahmed Hospital in Istanbul. Ebu'l-feyz Mustafa received his medical training from chief physician Ömer Efendi (d. 1724) ${ }^{61}$ Furthermore,

55 This manuscript may also be regarded as a miscellany, which includes pieces from various genres written in different hands. See Ömer Şifa'i, Hülasatü'l-Ebdan, Süleymaniye Library, Tekelioğlu 920.

56 See Cevad İzgi, Osmanlı Medreselerinde İlim (Istanbul: İz, 1997).

57 For a list of books given to chief physicians, first Molla Kasım, then isa Çelebi, for teaching purposes in 1580, see Topkapı Palace Museum Archives, D. 8228. It is worth noting that Ali Haydar Bayat had previously expressed his doubts about these two physicians having served as chief physicians of the empire. Emphasizing the fact that their names were not mentioned in any extant lists of the imperial chief physicians and that the same word hekimbaşı could be used for the directors of imperial hospitals, Bayat thought that they might have been the head physicians of the palace hospital. See Bayat, Osmanlı Devleti'nde Hekimbaşıllk, 44.

58 See Nükhet Varlık, "Books on Medicine: Medical Knowledge at Work," in Necipoğlu et al., Treasures of Knowledge, $527-555$.

59 In his thorough research on Ottoman learning, and its main sources in mathematical (riyazi) and natural (tabi $i$ ) sciences, Cevad İzgi provides detailed information together with archival evidence on which books were taught at Ottoman madrasas. Nonetheless, İzgi does not provide similar kinds of confirmation for the medical texts produced after the sixteenth century and confines himself to state that those new manuscripts on medicine were also used at the universities. Izgi thus takes for granted that almost all the medical texts produced in the seventeenth century and onward were actively taught and used in the hospitals, assuming that these institutions were the primary grounds for the consumption of new medical texts. The fact that he put all seventeenth- and eighteenth-century works under "Books Taught and Used at the Ottoman Hospitals" (Osmanlı Dârüşşifâlarında Okutulan ve Kullanılan Tıp Kitapları) is an indication of that presumption. For a detailed discussion of these books, see Cevad İzi, Osmanl Medreselerinde İlim (Istanbul: İz, 1997), 2:44-104.

6o On some of these new works, see Küçük, Science without Leisure, 143-166.

61 On Ebu'l-feyz Musțafa, see Bedizel Zülfikar Aydın, "Ebulfeyz Mustafa Efendi ve Ünlü Eseri Risale-i Feyziyye’ye Ait Yeni Bilgiler," Illmi Araştırmalar 6 (January 24, 2014): 289-294; and Mükerrem Bedizel Zülfikar Aydın, "18. Yüzyıla Ait 
he translated Ibn Sellum's Gayetü'l-Itkan fi Tedbiri Bedeni'l-Insan from Arabic to Ottoman Turkish, which demonstrates that he was part of this larger intellectual world that embraced many medical novelties.

In the introductory section of Summary of Medicine, Ebu'l-feyz Mustafa shares with his readers the sources he consulted in different subbranches of medicine, which he listed as four. When it comes to "the science of recipes" (terkibat) he mentions pharmacopeias of Süleyman Efendi (d. 1715?) and Nuh Efendi (d. 1707), apparently "prevalent and famous among the high and the low [echelons of society]." ${ }^{62}$ This information is of utmost importance for the purpose of the present discussion, especially because it comes from a renowned physician of the time. It is worthwhile to note that some of his other works, such as his prominent pharmacopeia The Blessed Treatise on the Language of Materia Medica (Risale-i Feyziyye fi Lugatil-MüfredatitTibbiye), also provided current information from his day. For instance, he meticulously noted whether a medicinal substance "has recently appeared" in the Ottoman lands or was known and in use before. ${ }^{63}$ Hence, we should pay close attention to Ebu'l-feyz Mustafa's observation about the circulation of particular medical texts, not only among the physicians, but also non-professionals.

An eighteenth-century copy of Summary of Medicine, the Bağdatlı Vehbi 1390 (hereafter BV) in Süleymaniye Library, deserves scrutiny for crucial divergences in its first pages and for including important manuscript notes, which may show the diversity of paratexts in Ottoman medical books. However, this particular manuscript might have not been under the radar of researchers since it was not included in some of the previous bibliographical works. ${ }^{64} \mathrm{I}$ would like to focus on its introduction, where an additional name and work appears among the sources Ebu'l-feyz Mustafa consulted: Ömer Şifa'i and his The Unique Gem. Comparing it to other extant copies reveals that the BV is the only one that emphasizes The Unique Gem as circulating at the hands of people from all walks of life. Compared to marginalia we usually encounter, such as glosses and other types of paratexts, this is certainly a more substantial intervention to the original text.

How can we, then, interpret that the BV has a reference to Ömer Şifa'i, whereas the other copies do not? One explanation might have to do with its copyist. A manuscript note indicates that the text was reproduced at the hands of Müstakimzade Süleyman Sa'adeddin (d. 1788), an eminent biographer and calligrapher. ${ }^{65}$ It has to be mentioned that Müstakimzade's teacher in calligraphy was Katibzade Mehmed Refi“ (d. 1769), a physician who also served as the chief physician of the empire from 1758 until his death. ${ }^{66}$ In addition, Müstakimzade was close to other distinguished physicians of the time such as Abbas Vesim (d. 1760), a medical student of Ömer Şifa'i, who followed a similar path in his artistic training and became one of Katibzade Mehmed Refi"s pupils in calligraphy. When he failed to receive a teaching position, Müstakimzade began to occupy himself with the sciences and copying books. He also wrote introductions (dibace) of some of Abbas Vesim's works, including Code of Vesim on New and Old Medicine (Düsturu'l-Vesim fi Tibbi'l-Cedid ve'l-Kadim), a voluminous masterpiece of the

Türkçe ‘Müfredat' Kitapları ve Türk Tıp Tarihindeki Yeri,” Tıp Tarihi Araştırmaları 7 (1998): 55-168. On Ömer Efendi (not to be confused with Ömer Şifa'i), see Bayat, Osmanlı Devleti'nde Hekimbaşlık, 91-94.

62 Ebu'l-feyz Mustafa, Hulasatü't-Tibb, Süleymaniye Library, Reșid Efendi 691, 64b; Istanbul University Rare Books and Manuscripts Library, T. 7117, 2b.

63 See Ebulfeyz Mustafa Efendi, Risâle-i feyziyye fî lügati'l-müfredâti't-tıbbiye, ed. Şaban Doğan (Istanbul: Değişim, 2011), $28,38-39,52-53,120$.

64 See îhsanoğlu et al., Osmanlı Tibbi Bilimler, 376-377. The editors provided four extant copies of Summary of Medicine, yet the BV is not among them. I could not obtain the copy at Dar al-Kütüb, Faharis al-Şarkiyya. However, I rely on the work of ihsanoğlu and his colleagues, in which they provided the relevant part of the introductory section shared among these four copies.

65 Ebu'l-feyz Mustafa, Hülasatü't-Tibb, Süleymaniye Library, Bağdatlı Vehbi 1390, 1a: "müstakimzade hattıyla gayet mu'teber kitabdur."

66 Ahmet Yılmaz, "Müstakimzâde Süleyman Sâdeddin," in TDV islâm Ansiklopedisi (Istanbul: Türkiye Diyanet Vakfı, 2006), 32:113-115. Bayat, Osmanl Devleti'nde Hekimbassllk, 109-115. See also İman Muhammed İssa, "Müstakim-zâde Süleymân Sa'dü’d-Dîn Efendi Mecelletü’n-Nisâb (Kişi, Eser, Yer Adlarının Açıklamalı Dizini)” (PhD diss., Ankara Üniversitesi, 1995); Alper Yıldırım, "Müstakimzade Süleyman Saadeddin'in Devhatü'l-Meşâyih Osmanlı Şeyhü'l-ìslamlarının Biyografileri Adlı Eserinin Transkipsiyon ve Değerlendirilmesi” (master’s thesis, Mustafa Kemal Üniversitesi, 2014); and Emrah Bilgin, "Devhatü'l-Meşâyih ve Zeyilleri (İnceleme-Tenkitli Metin-İndeks)" (PhD diss., Atatürk Üniversitesi, 2015). 
eighteenth century ${ }^{67}$ It is highly probable that Müstakimzade, not a practicing physician yet certainly a member of the circles of prominent physicians, put Ömer Şifa'i's name and his work The Unique Gem in the introductory section of Summary of Medicine, while reproducing the BV copy. In this case, a paratextual element (i.e., information about the copyist) reveals clues about how the text itself may have been altered. With these new layers added, this striking detail makes us rethink the journey of the original text by way of copying, reading, and studying, and probable changes that it went through until it reached the last reader: we, the researchers. Furthermore, it acts also as a reminder that some Ottoman intellectuals, not only physicians, were quite up-to-date about the medical scholarship being produced during their time and willing to contribute to some of its products by inserting their own knowledge.

The first folios of the BV also hint to how a particular manuscript tends to transform into almost a miscellany with the accumulation of intriguing reader/owner notes. The pages include short medical notes on the four elements (water, air, fire, and earth), their relation to the bodily humors, and the influence of humors on people's temperaments. There is also a famous verse by Ragib Pasha (d. 1763) recorded on the first folio:

A curious shop of wisdom is this old vault of heavens:

Anything one seeks may be found therein, except the specific cure to one's problem. ${ }^{68}$

These lines stand next to the ownership note and the date recorded by the owner: "From the books of humble Mustafa Mir. May God forgive him. Şevval 21, 1209 [May 11, 1795]." Although we cannot go into the details of all the paratext here, I should at least underline that there is also a "copy of a permission certificate" (izin tezkiresi sureti) for pharmacies (ispeçiyar) ispençiyar) on the pages that come before Ebu'l-feyz Mustafa's text. It acts as a template that reads, "So-and-so in so-and-so district of Istanbul requested to sell various drugs and distilled materials [literally waters] necessary for some physicians and patients. We are informed of and acknowledge the competence of so-and-so in the aforementioned art [of pharmacy]." Was the book owner in question a pharmacist? Or was he a pharmacist's apprentice, maybe wishing to open his own shop (taşra çıkmak), which would also have required the approval of the pharmacists' guild? ${ }^{69}$ Was he a novice in medicine, practicing the basics of the humoral theory by taking notes, using these blank pages? Since the copy of the permission also stresses "waters distilled from alembic" (inbikden taktir olunmuş sular), can we entertain the possibility that this particular reader might also be interested in other books on al/chemical procedures such as Ömer Şifa'i’s The Unique Gem to produce new drugs?

Many other questions may be added here and probably few could be answered at this point. However, similar investigations will enrich our understanding of early modern Ottoman medical scholarship, their readers, and the world surrounding them. By looking at paratexts, we can get a glimpse of the interaction between the reader and the manuscript, but also between a particular manuscript and other textual materials. A manuscript note with a clear reference to another author demonstrates not only how the reader engages with the codex in question but also how other texts are summoned for better contemplation. A recipe presumed to heal headaches scribbled in a medical manuscript next to a section on ailments of the head is both a response from the reader to what they just read and a contribution to the manuscript for its next reader. Other annotations can be difficult to make sense of; still they remain as traces from the previous readers of the manuscript.

If we go back to our reader and "contributor" to the AE copy of The Unique Gem, we should

67 See Müstakimzade Süleyman Sadeddin, Tuhfe-i hattâtîn, ed. Mustafa Koç (Istanbul: Klasik, 2014), 607. For another important work of the period that Müstakimzade copied, see Subhizade 'Abdu'l-'aziz, Kita'at-i Nekave fi Tercemet-i Kelimat-l Boerhave, Topkapı Palace Museum Library, H. 546.

68 “Turfe dükkan-1 hikemdür bu köhen tak-1 felek / Ne arasan bulunur derde devadan gayrı." I use András Riedlmayer's translation. See András J. Riedlmayer, "Ottoman Copybooks of Correspondence and Miscellanies as a Source for Political and Cultural History," Acta Orientalia Academiae Scientiarum Hungaricae 61, no. 1/2 (2008): 204.

69 I prefer "he" because Ottoman guilds were almost always men's world, though there were women medical practitioners (e.g., physicians, surgeons, oculists, midwives) trained in non-institutional environments. For more information on Ottoman guild system, see Eunjeong Yi, Guild Dynamics in Seventeenth-Century Istanbul: Fluidity and Leverage (Leiden: Brill, 2004). 
admit that we still do not know much about him/her. He or she, too, might be interested in and could have acquired other medical works of the period, such as the above-mentioned Summary of Medicine by Ebu'l-feyz Mustafa. What we do know is that the owner of the AE copy was not only interested in more scholarly medical texts of the period, but also those that would embrace more "popular" approaches to healing. For some, like this particular reader, the division between these subfields were not so strict, and alchemy and medicine, as two fields of science and knowledge production, could rather be viewed as closely related. Although we are far from establishing algorithms for readers' preferences used by modern online bookstores, we can at least confidently state that there were readers of medicine who were interested in both Ömer Şifa'i's and Nusret Efendi's cures in early modern Ottoman culture. Although the observations in the present work can only scratch the surface, many more insights regarding medical reading practices can be gleaned from hundreds of paratextual components waiting to be discovered in Ottoman medical manuscripts.

\section{Bibliography}

\section{Archival Documents}

Topkap1 Palace Museum Archives D. 8228.

\section{Manuscripts and Published Critical Editions}

Ebu'l-feyz Mustafa. Hulasatu't-Tıbb. Süleymaniye Library, Bağdatlı Vehbi 1390. . Hulasatu't-Tibb. Süleymaniye Library, Reşid Efendi 691. . Hulasatu't-Tibb. Istanbul University Rare Books and Manuscripts Library, T. 7117.

Ebulfeyz Mustafa Efendi. Risâle-i feyziyye fî lügati'l-müfredâti't-tıbbiye. Edited by Şaban Doğan. Cağaloğlu, Istanbul: Değişim, 2011.

Emîn Efendi. Osmanlı hayatından kesitler: Menâkıb-ı Kethüdâzâde el-Hac Mehmed Ârif Efendi. Edited by Hasan Gürkan and Hür Mahmut Yücer. Istanbul: İnsan Yayınları, 2007.

Fatîn Davud. Hâtimetü’l-Eş'âr (Fatîn Tezkiresi). Edited by Ömer Çiftçi. T.C. Kültür ve Turizm Bakanlığ1 Kütüphaneler ve Yayımlar Genel Müdürlüğü, 2013.

Gevrekzade Hafız Hasan. Nikris Risalesi. Topkap1 Palace Museum Library, H. 564.

Mehmet Süreyya. Sicill-i Osmanî. Edited by Nuri Akbayar and Seyit Ali Kahraman. Istanbul: Kültür Bakanlığı, Türkiye Ekonomik ve Toplumsal Tarih Vakfı, 1996.

Müderris Hasan Efendi. Terceme-i Tıbb-ı Cedid / Gayetü’l-Müna Fi Tedbiri'l Merza. Süleymaniye Library, Tahir Ağa Tekke 395

Müstakimzade Süleyman Sadeddin. Tuhfe-i hattâtîn. Edited by Mustafa Koç. Istanbul: Klasik, 2014 .

Ömer Şifa'i. Cevherü'l-Ferid Fi't-Tibbi'l-Cedid, Millet Library, Ali Emiri Tib 77.

- Cevherü'l-Ferid Fi't-Tıbbil-Cedid. Süleymaniye Library, Hamidiye 1020.

—. Cevherü'l-Ferid Fi't-Tibbi'l-Cedid. Süleymaniye Library, Nuruosmaniye 3497.

—. Cevherü'l-Ferid Fi't-Tıbbi'l-Cedid. Süleymaniye Library, Nuruosmaniye 3498. . Hülasatül-Ebdan, Süleymaniye Library, Tekelioğlu 920. . Mürşidü'l-Muhtar Fi 'ilmi'l-Esrar. Süleymaniye Library, Halet Efendi 753.

_. Mürşidü'l-Muhtar Fi 'ílmi'l-Esrar. Istanbul University Rare Books and Manuscripts Library, T. 9314 .

Şifä̈̈l-Eskam. Cerrahpaşa Tip Fakültesi, Institute of Medical History, 1195 (old no. 595).

Paracelsus. Paracelsus (Theophrastus Bombastus von Hohenheim, 1493-1541): Essential Theoretical Writings. Edited by Andrew Weeks. Leiden: Brill, 2008.

Starkey, George. Alchemical Laboratory Notebooks and Correspondence. Edited by William Royall Newman and Lawrence Principe. Chicago: University of Chicago Press, 2004.

Subhizade 'Abdu'l-'aziz. Kita'at-i Nekave Fi Tercemet-i Kelimat-ı Boerhave. Topkapı Palace Museum Library, H. 546.

Toderini, Giambattista. De la littérature des Turcs, Tome Second. Translated by Antoine de Cournand. Paris: Chez Poinçot, Libraire, rue de la Harpe, No. 135, 1789.

\section{Secondary Sources}

Acıduman, Ahmet. “Ankaralı Hekim Nidầî ve Ünlü Eseri Menâfiü’n-Nâs: XVI. Yüzyıldan Çocuk Hastalıkları ve Tıbbî Deontolojiye Bir Bakış.” Çocuk Sağlığı ve Hastalıkları Dergisi, no. 56 (2013): 151-167.

Aç1l, Berat, ed. Osmanlı Kitap Kültürü: Cârullah Efendi Kütüphanesi ve Derkenar Notları. Istanbul: NobelILEM Kitaplı̆̆ı, 2015.

Alp, Gökhan. “Ebûbekir Nusret Efendi Dîvânı.” Master's thesis, Kırıkkale Üniversitesi, 2015. 
Artun, Tuna. "Hearts of Gold and Silver: The Production of Alchemical Knowledge in the Early Modern Ottoman World." PhD diss., Princeton University, 2013.

Aycibin, Zeynep. "Kâtib Çelebi, Fezleke, Tahlil ve Metin." PhD diss., Mimar Sinan Güzel Sanatlar Üniversitesi, 2007.

Aydın, Ayten. "Ömer Şifaî̀nin Mürşid El-Muhtar Fî Illm El-Esrâr Adlı Eserinde Simya." Ankara Üniversitesi Osmanl Tarihi Araştırma ve Uygulama Merkezi Dergisi, no. 17 (2015): 1-11.

Aynur, Hatice, Müjgan Çakır, Hanife Koncu, Selim Sırrı Kuru, and Ali Emre Özyıldırım, eds. Mecmûa: Osmanlı edebiyatınin kirkambarı. Istanbul: Turkuaz, 2011.

Bachour, Natalia. Oswaldus Crollius und Daniel Sennert im frühneuzeitlichen Istanbul: Studien zur Rezeption des Paracelsismus im Werk des osmanischen Arztes Sālih b. Nasrullāh Ibn Sallūm al-Halabi. Freiburg: Centaurus, 2012.

- "Iatrochemistry and Paracelsism in the Ottoman Empire in the Sixteenth and Seventeenth Centuries." Intellectual History of the Islamicate World 6, no. 1/2 (2018): 82-116. https://doi.org/10.1163/2212943X-00601008.

Bayat, Ali Haydar. Osmanlı Devleti’nde Hekimbaşılık Kurumu ve Hekimbaşılar. Ankara: Atatürk Kültür Merkezi Başkanlığı Yayınları, 1999.

Bilgin, Emrah. "Devhatü'l-Meşâyih ve Zeyilleri (İnceleme-Tenkitli Metin-İndeks).” PhD diss., Atatürk Üniversitesi, 2015.

Chang, Ku-ming. "Alchemy as Studies of Life and Matter: Reconsidering the Place of Vitalism in Early Modern Chymistry." Isis 102, no. 2 (2011): 322-329. https://doi.org/10.1086/660141.

Ciotti, Giovanni, and Hang Lin, eds. Tracing Manuscripts in Time and Space through Paratexts. Berlin: De Gruyter, 2016.

Çelebi, illyas. "Havas İlmi." TDV İslam Ansiklopedisi. Vol. 16, 517-21. Istanbul: Türkiye Diyanet Vakfı, 1997.

Çınar, Serkan. "Ebubekir Nusret Efendi’nin Risale-i Nusret Efendi Adlı Eseri (İnceleme-Metin-Dizin)." Master's thesis, Karabük Üniversitesi, 2019.

Debus, Allen G. The Chemical Philosophy: Paracelsian Science and Medicine in the Sixteenth and Seventeenth Centuries, Volume I. New York: Science History Publications, 1977.

—. "The Philosophical and Medical Paracelsus. Paracelsianism and the Diffusion of the Chemical Philosophy in Early Modern Europe." In Paracelsus: The Man and His Reputation, His Ideas and Their Transformation, edited by Ole Peter Grell, 225-244. Leiden: Brill, 1998.

Değirmenci, Tülün. "Bir Kitabı Kaç Kişi Okur? Osmanlı'da Okurlar ve Okuma Biçimleri Üzerine Bazı Gözlemler.” Tarih ve Toplum Yeni Yaklaşımlar, no. 13 (Fall 2011): 7-43.

Fancy, Nahyan. "Medical Commentaries: A Preliminary Examination of Ibn al-Nafis's Shurūh, the Mūjaz and Subsequent Commentaries on the Mūjaz." Oriens 41, (2013): 525-545.

Fazlıŏlu, İhsan. Fâzıl Ali Bey [Ali El-iznikî], Accessed July 16, 2018. http://fazlioglu.blogspot.com/2018/o7/prof-dr-ihsan-fazlioglu-fazil-ali-bey-ali-el-izniki.html.

Fissell, Mary. "Popular Medical Writing." In The Oxford History of Popular Print Culture: Volume One: Cheap Print in Britain and Ireland to 1660, edited by Joad Raymond, 418-431. Oxford: Oxford University Press, 2011.

Fissell, Mary Elizabeth. "Introduction: Women, Health, and Healing in Early Modern Europe." Bulletin of the History of Medicine 82, no. 1 (2008): 1-17. https://doi.org/10.1353/bhm.2008.0024.

Gardiner, Noah. "Books on Occult Sciences." In Treasures of Knowledge: An Inventory of the Ottoman Palace Library (1502/3-1503/4), vol. 1, edited by Gülru Necipoğlu, Cemal Kafadar, and Cornell H. Fleischer, 735-765. Leiden: Brill, 2019.

Genette, Gérard. Paratexts: Thresholds of Interpretation. Cambridge University Press, 1997. https://doi.org/10.1017/CBO9780511549373.

Genette, Gérard, and Marie Maclean. "Introduction to the Paratext." New Literary History 22, no. 2 (1991): 261-272. https://doi.org/10.2307/469037.

Gökbilgin, M. Tayyib. "Hekim-Bashi." In Encyclopaedia of Islam, Second Edition, edited by P. Bearman, Th. Bianquis, C. E. Bosworth, E. van Donzel, W. P. Heinrichs. Brill Online, 2012. Accessed October 15, 2019. http://dx.doi.org.ezp-prod1.hul.harvard.edu/10.1163/1573-3912_islam_SIM_2849.

Görke, Andreas, and Konrad Hirschler, eds. Manuscript Notes as Documentary Sources. Beirut: Orient-Institut Beirut; Ergon Verlag Würzburg in Kommission, 2011.

Gurbuzel, Sumeyra A. "Teachers of the Public, Advisors to the Sultan: Preachers and the Rise of a Political Public Sphere in Early Modern Istanbul (1600-1675)." PhD diss., Harvard University, 2016.

Günergun, Feza. "Convergences in and around Bursa: Sufism, Alchemy, latrochemistry in Turkey, 150o1750." In Entangled Itineraries: Materials, Practices, and Knowledges across Eurasia, edited by Pamela H. Smith, 227-257. Pittsburgh: University of Pittsburgh Press, 2019.

Gür, Merve Nur. "Ali El-İznikînnin ‘Cevahir El-Esrar Fî Ma’arif El-Ahcar' Adlı Eserinin Çeviri ve İncelemesi." Master's thesis, Fatih Sultan Mehmet Vakıf Üniversitesi, 2016.

Haage, Bernard D. "Alchemy Il: Antiquity-12th Century." In Dictionary of Gnosis \& Western Esotericism, edited by Wouter J. Hanegraaff, 16-34. Leiden: Brill, 2006.

Healy, Margaret. "Popular Medicine." In The Ashgate Research Companion to Popular Culture in Early Modern England, edited by Andrew Hadfield, Matthew Dimmock, and Abigail Shinn, 309-322. Farnham: Ashgate Publishing Limited, 2014. 
Hirai, Hiro. "The Word of God and the Universal Medicine in the Chemical Philosophy of Oswald Croll." In Alchemy and Rudolf II: Exploring the Secrets of Nature in Central Europe in the 16th and 17th Centuries, edited by lvo Purš and Vladimír Karpenko, 381-385. Praha: Artefactum, 2016.

Hirschler, Konrad. "Reading Certificates (Samā‘āt) as a Prosopographical Source: Cultural and Social Practices of an Elite Family in Zangid and Ayyubid Damascus." In Manuscript Notes as Documentary Sources, edited by Konrad Hirschler and Andreas Görke, 73-92. Beirut: Orient-Institut Beirut; Ergon Verlag Würzburg in Kommission, 2011.

Hultin, Neil C. "Medicine and Magic in the Eighteenth Century: The Diaries of James Woodforde." Journal of the History of Medicine and Allied Sciences 30, no. 4 (1975): 349-366. https://doi.org/10.1093/ jhmas/XXX.4.349.

Hüseyin Gönel. "Nusret Ebubekir Efendi ve Sầib Şerhi Üzerine Bazı Notlar.” Turkish Studies 4, no. 6 (2009): 193-212.

İhsanoğlu, Ekmeleddin, Ramazan Şeşen, M. Serdar Bekar, Gülcan Gündüz, and Bulut Veysel, eds. Osmanlı tıbbi bilimler literatürü tarihi $=$ History of the literature of medical sciences during the Ottoman period. İlim tarihi kaynaklar ve araştırmalar serisi; no. 14. Istanbul: İslam Tarih, Sanat ve Kültür Araştırma Merkezi IRCICA, 2008.

İssa, İman Muhammed. "Müstakim-Zâde Süleymân Sa'dü’d-Dîn Efendi Mecelletü’n-Nisâb (Kişi, Eser, Yer Adlarının Açıklamalı Dizini).” PhD diss., Ankara Üniversitesi, 1995.

İzgi, Cevad. Osmanlı Medreselerinde İlim. Istanbul: İz, 1997.

Karabuçak, Kemal. "Ebubekir Nusret Divânı (İnceleme-Tenkitli Metin).” PhD diss., Sakarya Üniversitesi, 2018.

Klein, Joel A. "Chymical Medicine, Corpuscularism, and Controversy: A Study of Daniel Sennert's Works and Letters." PhD diss., Indiana University, 2014.

Küçük, Harun. Science without Leisure: Practical Naturalism in Istanbul, 1660-1732. Pittsburgh: University of Pittsburgh Press, 2020.

Leong, Elaine Yuen Tien. Recipes and Everyday Knowledge: Medicine, Science, and the Household in Early Modern England. Chicago: University of Chicago Press, 2018.

Liebrenz, Boris. "An Archive in a Book: Documents and Letters from the Early-Mamluk Period." Der Islam 97, no. 1 (2020): 120-171. https://doi.org/10.1515/islam-2020-0oo6.

Moran, Bruce T. Distilling Knowledge: Alchemy, Chemistry, and the Scientific Revolution. Cambridge, MA: Harvard University Press, 2005.

Newman, William. "From Alchemy to "Chymistry." In The Cambridge History of Science Vol 3: Early Modern Science, edited by Katharine Park and Lorraine Daston, 497-517. Cambridge: Cambridge University Press, 2006.

Newman, William R., and Lawrence M. Principe. "Alchemy vs. Chemistry: The Etymological Origins of a Historiographic Mistake." Early Science and Medicine 3, no. 1 (1998): 32-65. https://doi.org/10.1163/157338298Xooo22.

Ofer Hadass. Medicine, Religion, and Magic in Early Stuart England: Richard Napier's Medical Practice. University Park: Penn State University Press, 2018.

Okumuş, Necdet. "Ömer Şifâî Efendi." TDV İslam Ansiklopedisi. Vol. 34, 82-83. Istanbul: Türkiye Diyanet Vakf1, 2007.

Özkaya, Şule Yüksel. "Bir XIII. Yüzyıl Müellifi Ebû Bekir Nusret Efendi’nin 'Mâ-Hazara Fi't-Tıbb'r'-Rûhâni ve'l-Cismâni' Adlı Eserinin İncelenmesi ve Transkripsiyonu." Master's thesis, Marmara Üniversitesi, 2017.

Pagel, Walter. Paracelsus: An Introduction to Philosophical Medicine in the Era of the Renaissance. Basel: Karger, 1982.

- The Smiling Spleen: Paracelsianism in Storm and Stress. Basel: Karger, 1984.

Pormann, Peter E., and Emilie Savage-Smith. Medieval Islamic Medicine. Edinburgh: Edinburgh University Press, 2007.

Porter, Roy, ed. The Popularization of Medicine, 1650-1850. London: Routledge, 1992.

Principe, Lawrence. The Aspiring Adept: Robert Boyle and His Alchemical Quest: Including Boyle's "Lost" Dialogue on the Transmutation of Metals. Princeton: Princeton University Press, 1998.

. "Alchemy I: Introduction." Dictionary of Gnosis \& Western Esotericism, edited by Wouter J. Hanegraaff, 12-16. Leiden: Brill, 2006.

The Secrets of Alchemy. Chicago: University of Chicago Press, 2013.

Quinn, Meredith M. "Making Sense of Miscellanies: Houghton Library MS Turk 11, an Ottoman Mecmua." Harvard Library Bulletin 24, no. 1 (2013): 27-44.

Riedlmayer, András J. "Ottoman Copybooks of Correspondence and Miscellanies as a Source for Political and Cultural History." Acta Orientalia Academiae Scientiarum Hungaricae 61, no. 1/2 (2008): 201-214. https://doi.org/10.1556/AOrient.61.2008.1-2.17.

Ritter, Hellmut. "Autographs in Turkish Libraries." Oriens 6, no. 1 (1953): 63-90. https://doi.org/10.2307/1579235.

Savage-Smith, Emilie. "Drug Therapy of Eye Diseases in Seventeenth-Century Islamic Medicine: The Influence of the 'New Chemistry' of the Paracelsians." Pharmacy in History 29, no. 1 (1987): 3-28.

Schmidt, Jan. "The Occult Sciences and their Importance in Ottoman Culture; Evidence from Turkish 
Manuscripts in Dutch Public Collections." Osmanl Araştırmaları 23 (2003): 219-254.

Sezer Aydınl, Elif. “Unusual Readers in Early Modern Istanbul.” Journal of Islamic Manuscripts 9, no. 2/3 (2018): 109-131. https://doi.org/10.1163/1878464X-00902002.

Shefer-Mossensohn, Miri. Ottoman Medicine: Healing and Medical Institutions, 1500-1700. Albany: SUNY Press, 2009.

Shefer, Miri. "An Ottoman Physician and His Social and Intellectual Milieu: The Case of Salih Bin Nasrallah Ibn Sallum." Studia Islamica 106, no. 1 (2011): 102-123. https://doi.org/10.1163/19585705-12341254.

Snook, Edith. “The Women Know': Children's Diseases, Recipes and Women's Knowledge in Early Modern Medical Publications." Social History of Medicine 30, no. 1 (2017): 1-21. https://doi.org/10.1093/shm/hkwo88.

Terzioğlu, Arslan. "Ali Münşî.” TDV İslâm Ansiklopedisi. Vol. 2, 421-422. Istanbul: Türkiye Diyanet Vakfı, 1988.

Tuğluk, İbrahim Halil. "Abbas Vesîm Efendi; Hayatı, Eserleri, Edebî Kişiliği, Divanı'nın Tenkitli Metni ve İncelemesi.” PhD diss., Gazi Üniversitesi, 2007.

Tweed, Hannah C., and Diane G. Scott, eds. Medical Paratexts from Medieval to Modern: Dissecting the Page. Cham: Palgrave Macmillan, 2018.

Ünlü, Osman. "Ebubekir Nusret'in Sâib-i Tebrizî Şerhleri." Turkish Studies 4, no. 6 (2009): 442-455.

Uzluk, Feridun Nafiz. "Bursalı Hekim Ali Münşi Efendi." D.T.C.F. Dergisi 7 (1950): 329-337.

Varlık, Nükhet. Plague and Empire in the Early Modern Mediterranean World: The Ottoman Experience, 1347-1600. New York: Cambridge University Press, 2015.

"Books on Medicine: Medical Knowledge at Work." In Treasures of Knowledge: An Inventory of the Ottoman Palace Library (1502/3-1503/4), vol. 1, edited by Gülru Necipoğlu, Cemal Kafadar, and Cornell H. Fleischer, 527-555. Leiden: Brill, 2019.

Yerlioğlu, Akif Ercihan. "Paracelsus Goes East: Ottoman 'New Medicine' and its Afterlife." PhD diss., Harvard University, 2020.

Yi, Eunjeong. Guild Dynamics in Seventeenth-Century Istanbul: Fluidity and Leverage. Leiden: Brill, 2004.

Yıldırım, Alper. "Müstakimzade Süleyman Saadeddin'in Devhatü’l-Meşâyih Osmanlı Şeyhü’l-İslamlarının Biyografileri Adlı Eserinin Transkipsiyon ve Değerlendirilmesi.” Master's thesis, Mustafa Kemal Üniversitesi, 2014.

Yllmaz, Ahmet. "Müstakimzâde Süleyman Sâdeddin." TDV İslâm Ansiklopedisi. Vol. 32, 113-115. Istanbul: Türkiye Diyanet Vakfı, 2006.

Yılmaz, Coşkun, and Necdet Yılmaz, eds. Osmanlılarda Sağlık=Health in the Ottomans. Istanbul: Biofarma, 2006.

Zülffikar Aydın, Mükerrem Bedizel. “18. Yüzyıla Ait Türkçe 'Müfredat' Kitapları ve Türk Tıp Tarihindeki Yeri.” Tıp Tarihi Araştırmaları 7 (1998): 55-168.

- "Ebulfeyz Mustafa Efendi ve Ünlü Eseri Risale-i Feyziyye’ye Ait Yeni Bilgiler.” Ilmi Araştırmalar 6 (January 24, 2014): 289-294. 